\title{
DPMPTSP Sumedang Regency: The Policy Guidance of Entrepreneurship and Innovation under the New Normal of Economy
}

\author{
Susi Susanti Tindaon, HenyHandayani \\ shanty.tindaon@poltek.stialnabandung.ac.id \\ heny.handayani@poltek.stialanbandung.ac.id
}

\begin{abstract}
This study aims to see the effectiveness of investment license services innovation as an investment growth agent in the new normal era at DPMPTSP Sumedang Regency. The research method used is descriptive qualitative, with the number of informants is 8 people, consist of $1 \mathrm{Head}$ of licensing service division, 1 licensing service provider officer, 1 data information analyst and 5 community members. The data collection techniques used is library research and field studies which consist of observations, interviews, and documentation. The data analysis techniques used are data reduction, and verification which are interpreted qualitatively from the results of observations and interviews. Based on the results of the study, it is concluded that the licensing service innovation at DPMPTSP Sumedang Regency in general has been running but not yet optimal, considering that the licensing service program was already online-based, it can be seen from the 8 indicators studied. The results of the study found that there are several obstacles faced by DPMPTSP Sumedang Regency. Efforts were made to deal with obstacles are simplifying the process flow, having direct communication facilities, improving the SK template and requirements adjusted to the latest regulatory developments, transparently displaying the tracking application process, and adding monitoring and evaluation facilities and notifications.
\end{abstract}

Keywords: Effectiveness, Innovation, Investment License Services

\section{Introduction}

Entering thenew normal era, Indonesian government focuses on the mitigation of COVID-19 and the investment climate improvement. Indonesia is concerned in handling COVID19 and facing the new normalera. The Indonesian government has launched various policies to cope the risk of COVID-19 following its policies that focus on improving services for the community.

The current system supports the creation of excellent public service to fulfill the basic needs and civil rights for public goods, public services, and administrative services. To conduct these services, the government has created Law Number 25 of 2009 about Public Services as a legal basis, and perform it's obliged to provide public services to every citizen and resident to fulfill their fundamental rights and needs within the framework of public services as mandated in the Law.

The implementation of One-Stop Licensing Service is the activity of administering licensing and non-licensing whose management process from the application stage to the document issuance stage is carried out in one place. One of the expectations of the community about services is the services carried out by the government and other organizations following the times, social changes, and its dynamics (Vina, 2019: 70).

With the current situation inCOVID-19 pandemic, onlinebased media are needed or very useful for many parties because COVID-19 makes people struggle to do outside activities. People need something practical to get information or take care of their needs with electronic media, especially with rules from the government so that people can minimizeoutside activities. Activities through online-based media help many parties to be able to carry out their activities by just staying at home. The presence of this online-based media makes it easier and faster to carry out various kinds ofdaily activities (Poli, 2021: 2).

Further explained by LAN (2017) in (NurHandayani, 2020: 8 ) defines innovation as a process or result of development, utilization of knowledge mobilization, skills, and experience to create the new products either goods or service, new processes, new systems which provide more value. Innovation can also be interpreted as a creative ideas, new actions that are different from the previous ones; best practices, good practices, breakthroughs, and others. Although not all new ideas are categorized as innovations.

The central government through BKPM makes innovations in business licensing services from the center, namely OSS RBA which is a system that integrates all business licensing services that are under the authority of the Minister/Head of Institutions, Governors, or Regents/Mayors that are carried out virtually. Before OSS ARB existed, there was OSS1.1 which was based on a license-based approach. Recently, OSS RBA is based on a Risk-based approach which is divided into 4 types of risk, namely low risk, medium low risk, medium-high risk, and high risk. For low and mediumlow risks, the Business Identification Number (NIB) is immediately issued so it is not handled by the regional DPMPTSP.

Meanwhile, the Regional Government can develop a support system for the implementation of the OSS RBA System from the center following the norms, standards, procedures, and criteria set by the Central Government. The permits that are not fully available in the RBA OSS are generally Business Permits to Support Business Activities (PB UMKU), permit recommendations, and non-business 
permits. In this case, not all permits are in the RBA OSS, one of the innovations made is from the Investment and One-Stop Integrated Service (DPMPTSP) Office which is located in Sumedang, creating online information system through a website named SI ICE Mandiri.

Based on the website at https: //ptsp. sumedangkab. go. id/, SI ICE is an information system for licensing and nonlicensing services that allow applicants to download licensing decrees and print them independently. The public, as the permit applicants, are facilitated to download the decree (SK) and print it independently, which is an information system for licensing and non-licensing services. This information system is equipped with capabilities that can facilitate both from the applicant side (the community) and the officer side (DPMPTSP). Besides, there are several other innovations related to investment permits to complement the ARB OSS made by the center which is expected to be able to improve the investment in Sumedang Regency. Based on this policy, the authors are eager to conduct research on "The Effectiveness of Licensing Service Innovations as an Investment Growth Agent in the New Normal Era in Sumedang Regency, West Java"

\section{Methods}

In this study, the researcher used descriptive research methods using data collection techniques through library research, namely data collection techniques using a review study of books, literature, notes, and reports that have to do with the problem being solved (Nazir, 1998) and field studies consisting of observations, interviews, and documentation. Qualitative descriptive research aimed to describe the existing phenomena, both natural and artificial which focus on the characteristics, quality, and interrelationships between activities (Sukmadinata, 2011: 73). Meanwhile, the data analysis techniques used were data reduction and verification which were interpreted qualitatively from the results of observations and interviews (Sugiyono, 2012: 91).

So, descriptive qualitative research is a research conducted to determine the description of the problem under the study that pays more attention to the characteristics, quality, and interrelationships among activities.

\section{Results and Discussions}

This research focuses on the effectiveness of licensing service innovations at the Investment and One-Stop Integrated Service (DPMPTSP) Sumedang Regency, as an agent for the growth of the investment in the new normal era.

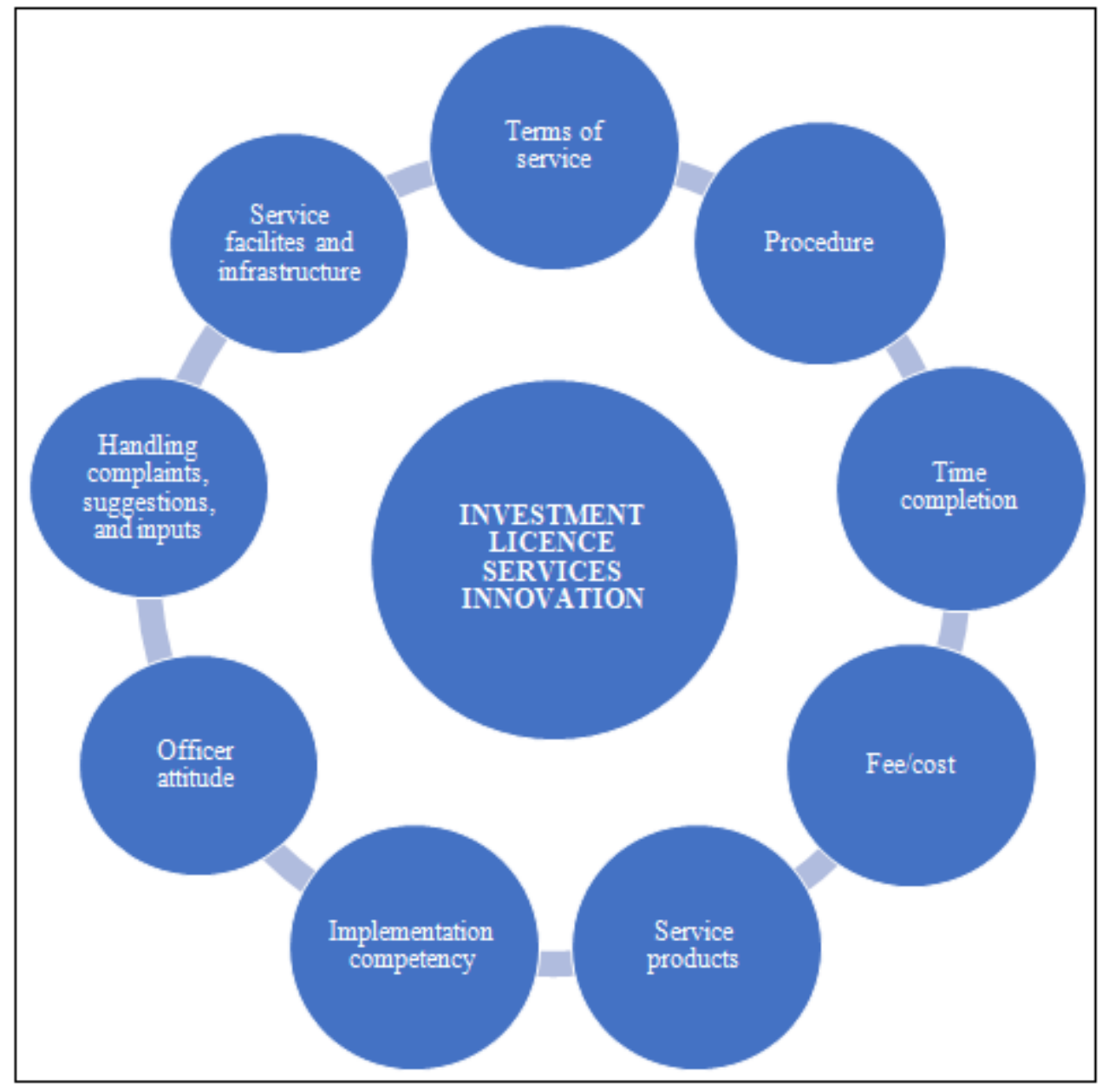




\begin{tabular}{|c|l|c|c|}
\hline No. & \multicolumn{1}{|c|}{ UNSUR PELAYANAN } & NRR/Unsur & $\begin{array}{c}\text { NRR } \\
\text { Tertimbang }\end{array}$ \\
\hline U1 & Persyaratan & 3,392 & 0,373 \\
\hline U2 & Prosedur & 3,384 & 0,372 \\
\hline U3 & Waktu pelayanan & 3,291 & 0,362 \\
\hline U4 & Biaya/tarif & 3,627 & 0,399 \\
\hline U5 & Produk layanan & 3,373 & 0,371 \\
\hline U6 & Kompetensi pelaksana & 3,417 & 0,376 \\
\hline U7 & Perilaku pelaksana & 3,451 & 0,380 \\
\hline U8 & Penanganan Pengaduan, Saran dan Masukan & 3,756 & 0,413 \\
\hline U9 & Sarana dan Prasarana & 3,529 & 0,388 \\
\hline & NILAI INDEKS PELAYANAN (JUMLAH NRR TERTIMBANG) & $\mathbf{3 , 4 3 4}$ \\
\hline & NILAI SKM ( NILAI INDEKS X 25) & $\mathbf{8 5 , 8 5 9}$ \\
\hline & MUTU PELAYANAN & BAIK \\
\hline
\end{tabular}

Notes:

\begin{tabular}{|l|l|c|c|}
\hline No & \multicolumn{1}{|c|}{ The Service Category } & NRR/Value & NRR/Valued Score \\
\hline U1 & Procedure & 3.392 & 0.373 \\
\hline U2 & Time completion & 3.384 & 0.372 \\
\hline U3 & Fee/cost & 3.291 & 0.362 \\
\hline U4 & Service product & 3.627 & 0.399 \\
\hline U5 & Implementation competency & 3.373 & 0.371 \\
\hline U6 & Implementer attitude & 3.417 & 0.376 \\
\hline U7 & Officer attitude & 3.451 & 0.380 \\
\hline U8 & Handling complaints, suggestion and input & 3.756 & 0.413 \\
\hline U9 & Service facilities and infrastructure & 3.529 & 0.388 \\
\hline \multicolumn{2}{|l|}{ SCORE OF INDEX SERVICE (THE TOTAL VALUED SCORE) } & 3.434 \\
\hline & INDEX SCORE X 25) & 85.859 \\
\hline & GERVICE QUALITY & Good \\
\hline
\end{tabular}

Source: Community Satisfaction Survey at DPMPTSP Sumedang Regency

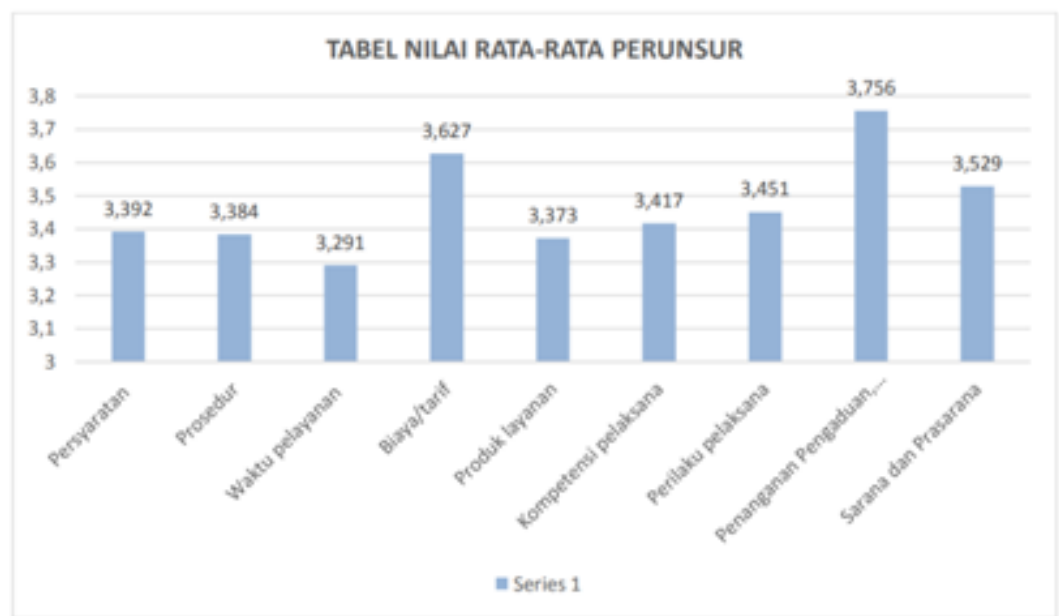

Source: Permenpan RB No. 14 Years 2017

The implementation of the effectiveness of licensing service innovations at the Investment and One-Stop Integrated Service (DPMPTSP) as an agent for the growth of the investment in the new normal era in Sumedang Regency, West Java, is as follows:

\section{1) Terms of Service}

Service requirements are benchmarks used in services and reference for service quality to the community to create fast, easy, affordable, and measurable services. At the Investment and One-Stop Integrated Service (DPMPTSP) Sumedang Regency, There are 30 types of permit requirements. The public can go to the website https: //ptsp. sumedangkab. go. $i d /$ and choose any type of service. In terms of service requirements, the respondents' assessment results have an average value of 3.392 .

Furthermore, on the website, it will be written: "see the requirements" what service users must require, a registration guide in the form of a video, and information on how long the process is and the validity period of the permit. Based on observations regarding service requirements, it is obtain some problems that have not run optimally such as application is rejected by the verifier, the applicant cannot correct the data entered on the Si ICE Mandiri form because once the data has submitted, all data is locked. Besides, there 
are Decree templates and requirements that are no longer relevant to the rules, so there are included suddenly. The last one is related to the registration at Si ICEMandiri, you can only use citizenship number (NIK) while foreign applicants do not need NIK because they do not have it.

\section{2) The mechanisms and Procedures}

The dimensions of service procedures for indicators of service availability standards are contained in the Decree of the Head of the Sumedang Regency Investment and OneStop Integrated Service Number: 382/PM.05.02/V/2021. Procedures or instructions for online licensing services and service processes that are easy and clear in implementation, the availability of procedures and instructions is available at DPMPTSP. It can be seen clearly from the Decree regarding Licensing and Non-Licensing Service Standards at the Investment and One-Stop Integrated Service office so that officers must inform the licensing procedures directly to applicants, and regarding the easy and clear service process, it can be said online service is better. The elements of the service mechanism and procedure system have the results of the respondent's assessment with an average value of 3.384 .

Furthermore, based on observations in the field, the licensing process is very dynamic in terms of regulation. So, there are new regulations for every year which make many SOPs that must be adjusted to the new regulations. Meanwhile, the process flow still needs to be simplified because it causes the rejection of files and data at the same time. Transparency of the process is still not transparent, only informal monitoring, so it is necessary to clarify the application process. The Limitation of property tax and vehicle tax happens, so it must regulate them. Requests for permission data are often incomplete because they are related to data uniformity. Sometimes, the name and NIK can be changed, so the applicant must provide the correct identity. At Si ICEMandiri 1, many features are no longer needed and there is also no Monitoring and Evaluation (money) facility and money notification related to the issued Decree.

\section{3) Service Completion Time}

In the dimension of service completion time, for indicators of clarity of time and effective time achievement in its implementation, there is clarity of time, namely where licensing applicants have received information about the clarity of time when applicants apply for making types of permits, and regarding the achievement of an effective time. It is said to be effective, this is in line with the Decree of the Head of the Office of Investment and One-Stop Integrated Services of Sumedang Regency Number: 382/PM.05.02/V/2021 concerning Service Standards for Licensing and Non-Licensing at the Investment Service and One-Stop Service. The decree also regulates the completion time of services according to the standards set by the system, so that the services provided run effectively. In terms of service requirements, the respondents' assessment results have an average value of 3.291.

Furthermore, based on the observations, there is no time limit to access because it is under the Regent's Regulation as well as the application and processing of permits during working hours. After the file is submitted and completed, the file will be processed in 5 days, maximum. The transparency of the technical recommendation process ensures certainty and clarity on the timing of the recommendation process. However, several cases were also found, for example, a mobile phone number that could not be contacted or was invalid. It makes the service completion longer.

\section{4) Service Fees and Cost}

In the dimension of a service fee, there are no other levies other than the costs stipulated in the regulations in their implementation. The existence of cost clarity is that it is known that the officers do provide information to the applicants that must be incurred and the expenses are only intended for applicants to issue building permits as stated in the Licensing Retribution contained in Sumedang Regent Regulation No.30 of 2017, as well as other free/nonretribution permits. In terms of service requirements, the respondents' assessment results have an average value of 3.627 .

Furthermore, based on the observation, it can be stated that there are no other levies other than the fees set according to the regulations. It can be seen from the absence of other levies that have been issued, namely the absence of the applicant's habit of delegating the task of drawing a plan which should be an applicants' job.

\section{5) Product and type service specifications}

In the dimensions of service products, the services run smoothly and produce satisfaction for consumers in terms of quantity. The quality starts from the submission to the end of the service process must be under procedures, and can be managed smoothly and efficiently. In terms of service requirements, the respondents' assessment results have an average value of 3.373 .

Furthermore, based on the observations, the service has not run smoothly for the workflow of verifier and the applicant which can still be passed. The applicant can still apply even though the form is empty and the initial work of the verifier is inconsistent.

\section{6) Service implementer competence}

In the dimension of service implementer competence, the officers must be responsible for service implementation. The implementation is from service providers who have qualifications of proficiency in the IT field. The officer should be under proficiency qualifications in the IT field. The officers need to be qualified before finally being sent to the BKD for the placement. In terms of service requirements, the respondents' assessment results have an average value of 3.417 .

Furthermore, the officers are already responsible for providing services. If there is still lacks of requirements then the officers always inform it as soon as possible via direct information or telephone to each applicant. The service always conducts an evaluation of the performance of each employee which is adjusted by looking at the Community Satisfaction Survey Report and several complaints that are accommodated in the complaint field, it is used as evaluation material. Sometimes the applicant's understandings of the verifier are different, so the file is different. The applicants 
send the file in the form of a JPG or PDF. When the applicant has applied, the applicant can still enter the file on the requirements, thus it makes the verifier unable to find out the new documents which have been uploaded.

\section{7) Officer attitude}

The behavioral dimensions of officer attitude greatly affect the applicants or the people who receive these services. The officers as public service providers must have the expertise, creativity, and abilities regarding the nature and behavior of providing services to the community. In terms of service requirements, the respondents' assessment results have an average value of 3.451 .

Furthermore, the behavior of service implementers is following the standards that have been set. This can be seen from the observations and community satisfaction surveys that have been carried out by the DPMPTSP.

\section{8) Handling complaints, suggestions, and inputs}

Handling of complaints, suggestions, and inputs is the procedure for implementing complaints handling and the following-up. The complainant usually submits a complaint by telephone, email, facsimile, or fills out a complaint form either through the website or in person. In the table above, it can be seen that the respondents' assessment of the 9 service elements showed a good value, and the highest rating from the respondents was the handling of complaints, suggestions, and input with an average value of 3.756 .

Furthermore, the officer can record the data of the complainant, and a copy of the form that has been filled out. The competent authority or person in charge is required to respond to the form of a written decision which is sent to the complainant, no later than thirty days after the objection is recorded in the complaint register. The complainant who objects to or is dissatisfied with the decision of the competent authority has the right to submit a dispute resolution of the complaint return no later than fourteen working days. Based on observations, it is clear that DPMPTSP has provided a form on the website where the complaint is private and the identity of the community is confidential.

\section{9) Service facilities and infrastructure}

In the dimensions of service facilities and infrastructure, they are complete such as a large waiting room and adequate parking space so it provides comfort to the community. In terms of service requirements, the respondents' assessment results have an average value of 3.529 .

Furthermore, based on observations, it can be seen that the facilities and infrastructure can support the service fully maximized. The existing infrastructure at the Investment and One-Stop Integrated Service office is good. It is under the Decree of the Head of the Investment and One-Stop Integrated Service Number: 382/PM.05.02/V/2021 Sumedang regency.

The problems that occur in the Effectiveness of Investment Licensing Service Innovations as Agents of Investment Growth in the New Normal Era

1) Terms of Service a) If the application is rejected by the verifier, the applicant cannot correct the data entered on the $\mathrm{Si}$ Ice Mandiri form

b) There are Decree templates and requirements that are no longer relevant to the rules

c) The registration on $\mathrm{Si}$ Ice Mandirionly uses a citizenship number.

2) The Mechanisms and Procedures

a) The steps still need to be simplified

b) Process transparency is still not transparent, only as monitoring.

c) Inspection restriction of property taxand vehicle tax

d) Permission data requests are often incomplete

e) Name and citizenship number can sometimes be changed

f) Many features are no longer needed at $\mathrm{Si}$ Ice Mandiri 1.1.

g) There are no monev facilities and monev notifications related to the issued Decree

h) There is still a lack of tools to calculate the number of applicants affected by KSWP

3) Service completion time

a) Many phone numbers that can't be contacted and even invalid

b) The time for the application service and the permit process is not limited to the access time

c) Transparency of technical recommendation process

4) Service Fees and Cost

a) There is clarity on the rates that are determined and ensure that there are no other levies other than the fees set according to the regulations, and their implementation is appropriate

5) Product type service specifications

a) The workflow of the verifier and the applicant can still be passed

6) Service implementer competence

a) The different understanding between the applicant and verifier

b) When the applicant has submitted, the applicant can still enter the file on the requirements

7) Officer attitude

a) The service implementers are under the standards that have been set.

8) Handling complaints, suggestions, and input

a) DPMPTSP has provided a form on the website of SI ICE Mandiri where the complaint is private and the identity of the community is confidential.

9) Service facilities and infrastructure

a) The existence of the service and infrastructure at the Investment One-Stop Integrated Service office is following the Decree of the Head of the Sumedang Regency Number: 382/PM.05.02/V/2021.

The following up action in the Effectiveness of Investment Licensing Service Innovations as Agents of Investment Climate Growth in the New Normal Era

1) Terms of Service

a) Open requester space to edit data

b) Fixed Decree templates and requirements adjusted to the latest regulatory developments

c) Provide registration space using Citizenship number and Passport

2) The mechanisms and Procedures 
a) Steps simplification

b) Show transparently the tracking application process

c) The Inspection of property tax and vehicle tax when the applicant declares that he has completed his obligations

d) In applying for a permit, the applicant is forced to complete all the forms in the $\mathrm{Si}$ Ice Mandiri application

e) Lock the applicant's citizenship number and name

f) Remove unused features

g) Provide monev facilities and monev notifications related to issued decrees

h) Introducing the Digital Signature feature

3) Service completion time

a) Registration is forced to be notified to the phone number via SMS

b) Limitation of application and permit process according to working hours

c) Showing in detail the recommendation steps

4) Service Fees and Cost

a) There is clarity on the rates that are determined and ensure that there are no other levies other than the fees set according to the regulations, and their implementation is appropriate

5) Product type service specifications

a) Lock the workflow so it's clear, step by step

6) Service implementer competence

a) There is a direct communication facility between the verifier and the applicant through Si ICE Mandiri application

b) Lock all activities that can be done by the applicant

7) Officer attitude

a) The service implementers are following the standards that have been set.

8) Handling Complaints, suggestions, and input

a) The DPMPTSP has provided a form on the website where the complaint is private and the identity of the community is confidential.

9) Service facilities and infrastructure

a) The existence of the service and infrastructure at the Investment One-Stop Integrated Service office is under the Decree of the Head of the Sumedang Regency Number: 382/PM.05.02/V/2021.

\section{Conclusion}

Based on the results of the study, the following conclusions were drawn:

1) The effectiveness of licensing services, in general, has been conducted optimally. Several indicators have been realized in its implementation such as service requirements, service mechanism systems and procedures, service completion time, product and type of service specifications, and competence of service implementers, service fees and costs, the behavior of service implementers, handling of complaints, suggestions, and inputs, and service facilities and infrastructure. In the table above, it can be seen that the respondents' assessment of the 9 service elements showed a good value, and the highest rating from the respondents was the complaint handling, suggestions, and input with an average value of 3.756 .
2) The problems faced include service requirements, service mechanism systems and procedures, service completion time, product and service type specifications, and service implementer competencies, service fees and cost, officer attitude, complaint handling, suggestions and input, and service facilities and infrastructure.

3) Efforts to cope the problems, namely:

a) The simplification steps

b) Open requester space to edit data

c) Lock all activities that can be done by the applicant

d) Lock the workflow so it's clear, step by step

e) There is a direct communication facility between the verifier and the applicant through the Si ICE Mandiri application

f) Fixed Decree templates and requirements adjusted to the latest regulatory developments

g) Show transparently on the tracking application process

h) The Inspection of property tax and vehicle tax when the applicant declares that he has completed his obligations

i) In applying for a permit, the applicant is forced to complete all the forms in the $\mathrm{Si}$ ICEMandiri application

j) Lock the applicant's citizenship number and name

k) Provide registration space using citizenship number and passport

1) Registration is forced to be notified to the phone number via SMS

m) Remove unused features

n) Limitation of application and permit process according to working hours

o) Showing in detail the recommendation steps

p) Provide monev facilities and monev notifications related to issued decrees

Based on the results, the author provides recommendation to create a better online-based permits service implementation, both in implementation and permits. Furthermore, DPMPTSP should focus on several indicators that have not been implemented and need to be improved, such as an investment.

\section{References}

[1] Arif Januari: Efektivitas Pelayanan Administrasi Perizinan Dengan Sistem Sms Gateway Di Dinas Penanaman Modal Dan Pelayanan Terpadu Satu Pintu Kota Medan. Universitas Sumatera Utara. (2017)

[2] Nazir: Metode Penelitian. Ghalia Indonesia. Jakarta. (1998)

[3] Handayani, Nur: Inovasi Pelayanan Publik di Mall Pelayanan public Sumedang. Lemabga Penelitian dan Kajian Intitut Pemerintahan dalam Negeri. (2020)

[4] Pedoman Inovasi Pelayanan Publik. Jakarta: LAN

[5] Stevani A. P Polii: Efektivitas Informasi Pelayanan Perizinan Melalui Website Dalam Meningkatkan Kualitas elayanan Publik Di Dinas Penanaman Modal Dan Pelayanan Terpadu Satu Pintu (Dpm-Ptsp) Kota Manado. Jurnal Politico Vol 10, No 4. (2021)

[6] Sugiyono: MetodePenelitianKuantitatif fan R\&B. Bandung: Alfabeta. (2012) 
[7] Vina Savinatunazah: Efektivitas Pelayanan Perizinan Berbasis Online Di Dinas Penanaman Modal Dan Pelayanan Terpadu Satu Pintu Kabupaten Ciamis. Dinamika: Jurnal Ilmiah Ilmu Administrasi Negara. (2019)

[8] " " , https: //ptsp. sumedangkab. go. id/ 